Bryn Mawr College

Scholarship, Research, and Creative Work at Bryn Mawr College

Classical and Near Eastern Archaeology Faculty

Research and Scholarship

Classical and Near Eastern Archaeology

1985

\title{
Ins and Outs of the Archives Rooms at Pylos: Form and Function in a Mycenaean Palace
}

T. G. Palaima

James C. Wright

Bryn Mawr College, jwright@brynmawr.edu

Let us know how access to this document benefits you.

Follow this and additional works at: http://repository.brynmawr.edu/arch_pubs

Part of the Classical Archaeology and Art History Commons, and the History of Art, Architecture, and Archaeology Commons

\section{Custom Citation}

Palaima, Thomas G., and James C. Wright. 1985. Ins and Outs of the Archives Rooms at Pylos: Form and Function in a Mycenaean Palace. American Journal of Archaeology 89:251-262.

This paper is posted at Scholarship, Research, and Creative Work at Bryn Mawr College. http://repository.brynmawr.edu/arch_pubs/48

For more information, please contact repository@brynmawr.edu. 


\title{
Ins and Outs of the Archives Rooms at Pylos: Form and Function in a Mycenaean Palace*
}

\author{
THOMAS G. PALAIMA AND JAMES C. WRIGHT
}

\begin{abstract}
In this article we examine archaeological and epigraphical evidence pertaining to the architectural reconstruction of the Archives Rooms in the Palace of Nestor at Pylos, with the aim of understanding how the rooms fit into the total architectural layout of the palace and how the records within them relate to scribal and work activity in and around the palace. We reconstruct two external doors into the Archives Complex, a primary door in the inner room and a secondary door in the outer one. This suggested reconstruction best accommodates the discernible patterns of scribal activity conditioned by architectural modifications to the overall palace plan in late LH IIIB. Our reconstruction also suits the function of the Archives Rooms as the central focus of record-keeping activity in the palace.
\end{abstract}

While excavating under the direction of Carl W. Blegen in 1939 at the site of Ano Englianos, William A. McDonald discovered the first Linear B tablets on the mainland of Greece in a two-room complex that, through excavation in the years 1952-1964, was found to be in a prominent and central location at the major southeastern entrance to the Palace of Nestor (ill. 2: Rooms 7-8). This two-room suite yielded by

\footnotetext{
* The authors wish to thank Mabel L. Lang and Cynthia Shelmerdine for participating with them in an open seminar at Bryn Mawr College in March 1982, during which the problems addressed in this article were first considered. Thanks are also owed to the University of Cincinnati Archaeological Excavations and E. Tucker Blackburn for making microfilm copies of the original excavation notebooks available to Palaima, who wishes to acknowledge also the characteristically generous assistance of Emmett $\mathrm{L}$. Bennett, Jr. Ingo Pini kindly shared with us the latest information on Linear A sealings. The completion of this study would not have been possible without the help of an Alexander von Humboldt fellowship (Wright) held at the Archaeological Seminar of the Philipps University, Marburg, and sponsored by Professor Bernard Andreae, and an ACLS fellowship for postdoctoral research at the Institute for Research in the Humanities of the University of Wisconsin (Palaima). Bruce Redford and Cynthia Shelmerdine helped greatly in the revision of this text for publication.

The abbreviations used in the footnotes are those given in $A J A$ 82 (1978) 3-10 with the following additions:

MT 2: $\quad$ E.L. Bennett, Jr., The Mycenae Tablets 2 (TAPS n.s. 48:1, 1958).

PCA: C.W. Shelmerdine and T.G. Palaima eds., Pylos Comes Alive: Industry and Administration in a Mycenaean Palace (New York 1984).

$P N: \quad$ C.W. Blegen and M. Rawson, The Palace of Nestor at Pylos in Western Messenia 1 (Princeton 1966).
}

far the largest number of Linear B tablets that has ever been discovered in a single location. ${ }^{1}$ Blegen correctly referred to the two rooms as the Archives Complex, and in fact they may have contained the only genuine archives of Linear B documents that have yet been found. ${ }^{2}$ Despite their obvious importance, the precise nature and function of these rooms have never been studied in detail. We do not know how these archives fit into the general scheme of scribal activity in the palace, nor is it clear how the rooms themselves fit into the total architectural layout, which must have determined the patterns of scribal and other work. How did the scribes use these two rooms? How did their work there relate to their activities elsewhere in the palace? What do the placement and plan of the Archives Complex (hereafter AG) reveal about the architectural conception of the palace and its overall system of organization?

We ask these specific questions in the hope that by answering them we may gain insights into the function of the whole palace as well as of its many separate parts. Such an attempt requires coordinating analysis of the written documents with that of the architectural

\section{PTT 1, 2: E.L. Bennett, Jr. and J.-P. Olivier, The Pylos Tablets} Transcribed, Parts 1 and 2 (Rome 1973 and 1976).

Reference will be made to excavation notebooks by name (year) and page number. Room numbers are those appearing on the general site plan (ill. 2). Reference to findspots of tablets from the Archives Complex is according to the grid in ill. 6, in which the Archives Complex is divided into $1 \mathrm{~m}$. squares. Within each meter square a $10 \mathrm{~cm}$. grid with the same system of numeration and the same orientation should be understood. Location is then designated by $1 \mathrm{~m}$. square (bold) and $10 \mathrm{~cm}$. square (plain), thus: 1333, 6483, etc. See PTT 2.23. All illustrations are by Wright.

${ }^{1}$ Of the more fully preserved tablets from Pylos, 767 were found in or obviously displaced from Rooms 7 and 8 . In contrast, Mycenae, Thebes and Tiryns together have produced fewer than 150 inscribed tablets, and the two possible archives complexes at Knossos contained only 293 (Bureau C) and 261 (Bureau I) respectively. A detailed statistical breakdown of the number and types of Linear B inscriptions at different sites is given by A. Bartoněk, "The Linear B Series and Their Quantitative Evaluation," Res Mycenaeae (Akten des VII. internationalen mykenologischen Colloquium in Nürnberg vom 6.-10. April 1981, Göttingen 1983) 15-27.

${ }^{2}$ For a discussion of the use of the term "archives," $\rightarrow$ M. de Jong Ellis, "Correlation of Archaeological and Written Evidence for the Study of Mesopotamian Institutions and Chronology," AJA 87 (1983) 497, n. 2, and 499. The special characteristics of Linear $\mathrm{B}$ archives are discussed by J.-P. Olivier, "Administrations at Knossos and Pylos: What Differences?" PCA 15-17. 


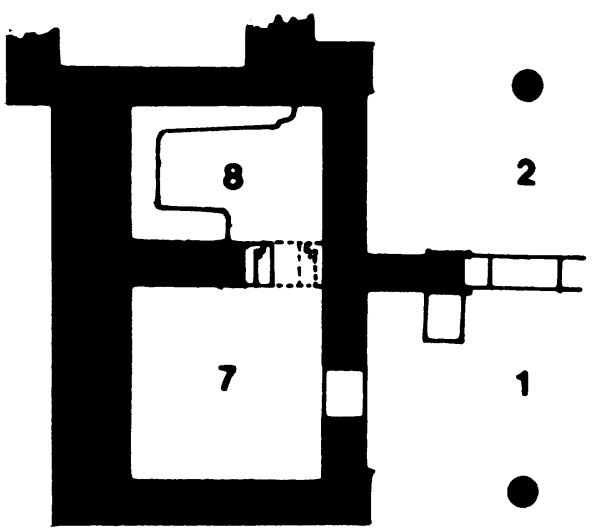

a

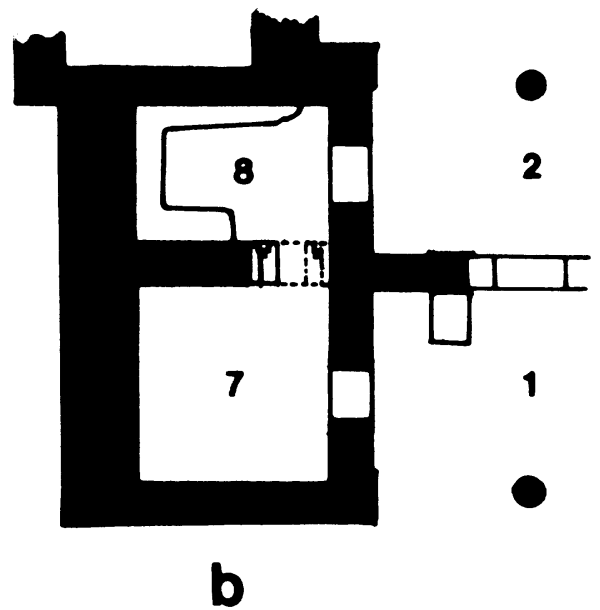

Ill. 1. a) Pylos, Archives Complex as restored by Blegen; b) Restoration suggested by Palaima and Wright

organization of the palace. In doing so we consider three questions: 1. Did Mycenaean scribes and workers move through the Palace of Nestor in definite, discernible patterns? 2. Was the work of scribes inside the AC significantly different from their work outside in the workshops and storerooms of the palace? 3. How were daily activities in different parts of the palace related? Insofar as we can provide answers to these questions, we are able to explain the design and purpose of individual parts of the palace and ultimately to consider how this information reflects on the organization, function and role of palatial complexes in Mycenaean economy and society.

The Archives Rooms at Pylos are especially suitable for this kind of study because, while they form a simple architectural unit, they nevertheless provide abundant information about their plan and use. Two main types of evidence show how they were integrated into the palace as a whole: 1) the architectural arrangement of the two-room suite and of comparable units within the Palace of Nestor; 2) the Linear B tablets and the evidence they yield about scribal activity and movement.

We begin by re-examining the evidence for Blegen's reconstruction of the rooms. Blegen described the $\mathrm{AC}$ as a two-room suite of which the exterior room (ill. 1a: Room 7) "was probably the office of the tax collector," while the interior room (ill. 1a: Room 8) "must have served principally to store the rec-

${ }^{3}$ PN 92-93.

${ }^{4} P N 96$.

${ }^{5} P N 93$.

"The perceptible widening of the "chasm" of the robbed-out wall at this point, as if for removal of $a$ threshold block, is dupli- ords." ${ }^{3}$ The exterior room, according to Blegen, was entered from outside the palace, before one passed through the gateway of the outer Propylon (ill. 1a: doorway between Areas 1 and 2). The AC as excavated, however, was incomplete (ill. 2); the surrounding walls of Rooms 7 and 8 had been robbed out, perhaps in the late seventeenth century when the foundations were mined for stone-as dated by a coin of the last Doge of Venice found in the eastern robbers' trench, dubbed by Blegen "the Chasm." ${ }^{4}$ Thus the excavators had to rely on inference in restoring an outer door directly into Room 7. Blegen noticed that the sentry stand of the southern Propylon (within Area 1) is located on the left side of the gate, whereas the other two stands in the palace (within Areas 4 and 5) are set to the right of their respective doorways. Blegen explained the anomalous position of the stand in the southern gate by suggesting that it was deliberately placed between two doorways, that of the Propylon and the hypothetical door into Archives Room 7. By this arrangement the sentry "could control those entering what may have been a treasury office as well as those going straight on into the palace." 5

Additional evidence in support of Blegen's reconstruction is lacking. ${ }^{6}$ During the course of excavation, Emmett L. Bennett, Jr., suggested another possibility: that the main door into the $\mathrm{AC}$ was located in Room 8 , so that the suite was accessible only from the interior of the palace. ${ }^{7}$ Bennett thus emphasized the connection between the records in the $\mathrm{AC}$ and the in-

cated along the course of the robbers' trench in Room 8. This feature should not, therefore, have been used as a supporting argument only for the door in Room 7; see PN 97.

${ }^{7} P N 97$. 


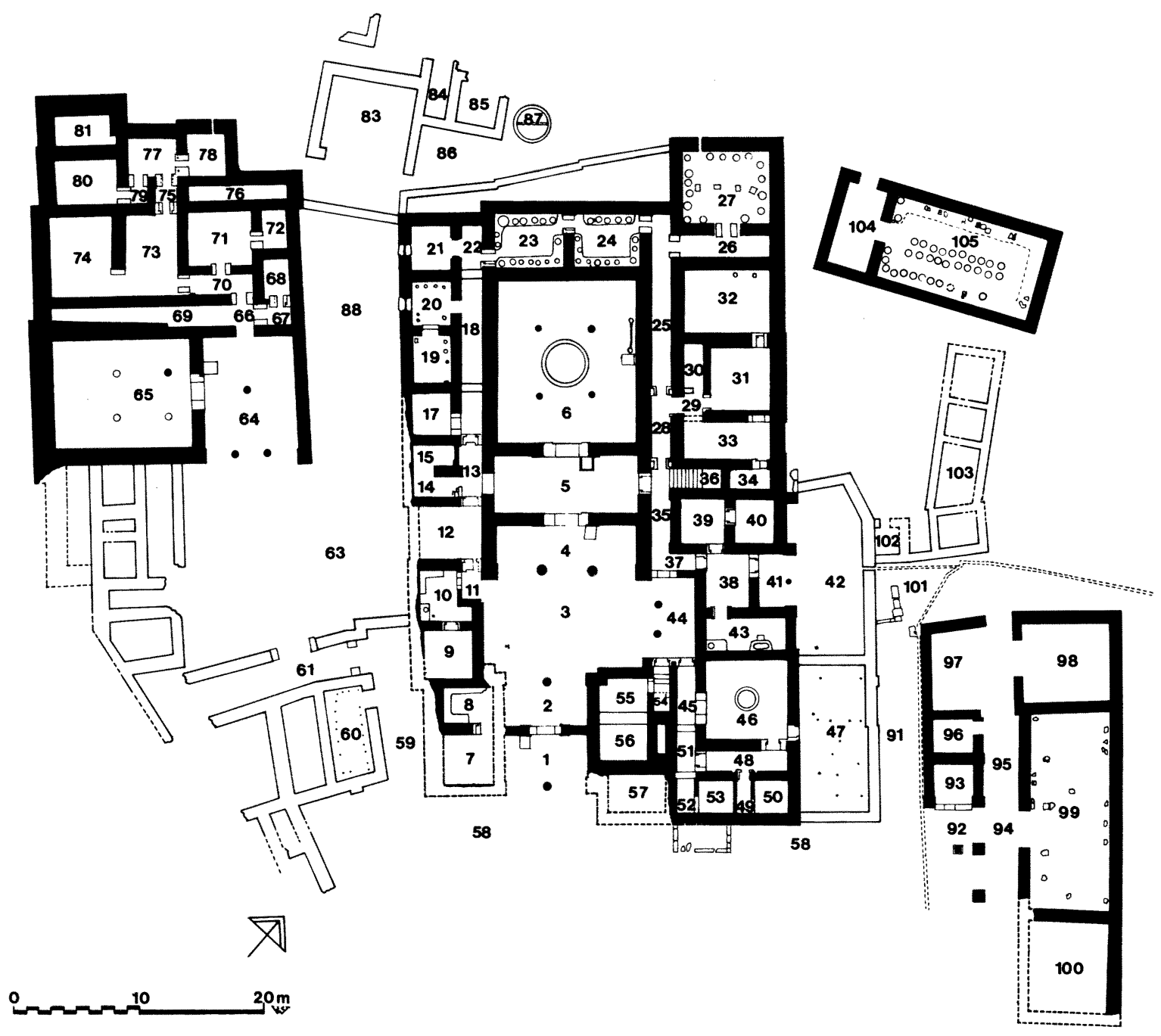

III. 2. Pylos, plan of final state of the Palace of Nestor

ternal activities of the Palace of Nestor. In support of his suggestion he observed that joining fragments of Linear B tablets were found on either side of the Chasm, in Room 8 and in Area 2, the inner hall of the Propylon. ${ }^{8}$ This distribution of tablets could be explained by spillage through a doorway when the palace was destroyed. As Blegen pointed out, however, the post-antique disturbance of the foundations could also have been responsible. He was willing to entertain the idea that "it may have been useful to the keeper of the economic records to have a doorway to

\footnotetext{
${ }^{8} P N$ 93. For example, one component of Tablet Aa 701 was found in grid 2736, its other two in the "Chasm" and grid 5450. Bennett offers a full discussion of findspots in the AC in "The FindSpots of the Pylos Tablets," Mycenaean Studies (Madison 1964) 241-52. A complete concordance of findspots by tablet is given in PTT 2.27-68. Rechecking of the excavation notebooks has enabled
}

the inner stoas just as well as the one we have likewise conjectured to have given access to the outer portico of the Propylon." But this idea was not incorporated in the reconstructed plan which was published.

In restoring a single door into the AC in Room 7, Blegen concentrated solely on evidence in the immediate area of the AC. He did not consider the relationship of the AC and its tablets to other records and rooms in the palace. Thus it seems worthwhile to examine the problem from this wider perspective. Our approach here is based on several propositions. First,

Palaima to identify the findspots more precisely; these data are incorporated in a monograph, The Scribes of Pylos, recently submitted for publication. Minor discrepancies between Bennett's lists and the findspots given in this article reflect Palaima's research. ${ }^{9}$ PN 97. 
we maintain that it is possible to infer patterns of movement in the palace by analyzing the architecture in conjunction with the distribution of inscribed materials. We follow Blegen in assuming that the platforms before the three principal doorways were for guards to stand on, and that it was conventional to place the guard on the right side of a potential intruder. ${ }^{10}$ Second, we propose that the direction in which doors open into the rooms and corridors of the palace indicates the primary direction of traffic through them. If a door opens into a room or corridor, the primary direction is that of the door, inward. ${ }^{11}$ Our last proposition is that Mycenaean palatial architecture tended to be modular, to repeat elements of design. ${ }^{12}$

First, let us consider how doors indicate movement. Illustration 3 shows the plan of a typical threshold at Pylos (in Rooms 39-40) which consists of three lime-
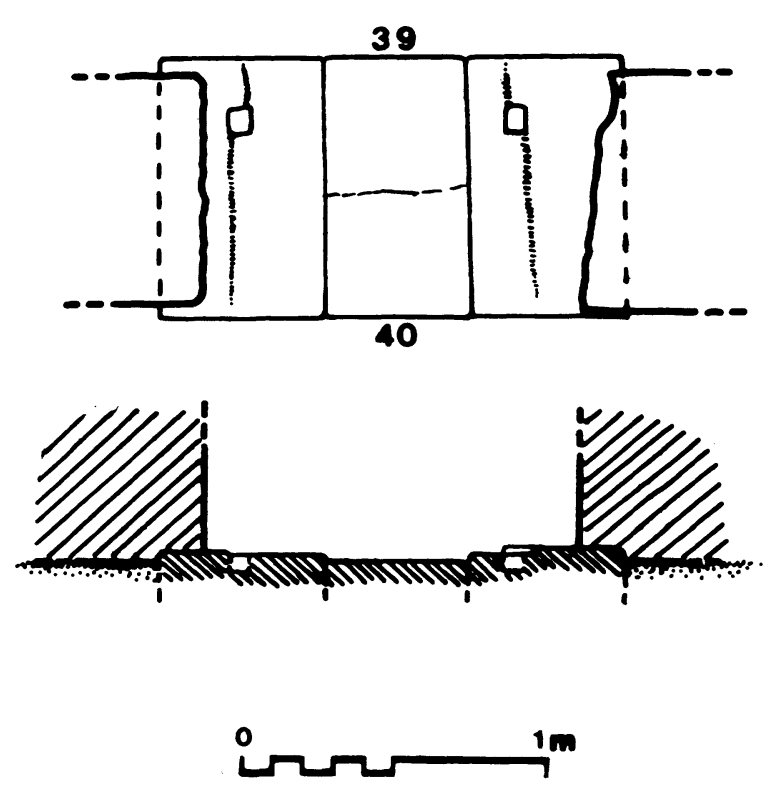

Ill. 3. Pylos, plan and section of doorway between Rooms 39 and 40

\footnotetext{
10 This principle is commonly employed in entrances to fortifications and is based on the convention of carrying a shield on the left side and offensive weapons on the exposed right. G. Mylonas, $M y$ cenae and the Mycenaean Age (Princeton 1966) 53-55, does not accept that these are guard stands; rather he suggests they were for torch stands for lighting at night.

${ }^{11}$ Joseph W. Shaw first suggested this idea to Wright during a
}

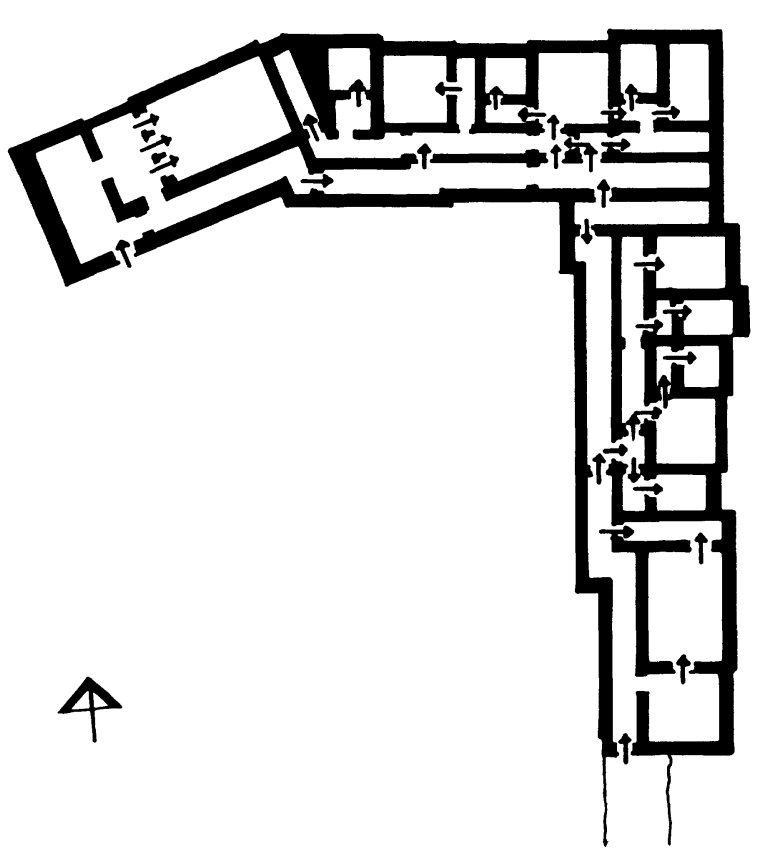

IIl. 4. Gla, plan of residence showing direction in which doors open

stone slabs spanning the doorway. On the lateral slabs are impressions in vitrified wall packing of the wooden doorjambs that once sheathed the ends of the walls on either side. In front of these impressions the slabs are rabbeted to receive the leaves of the closed doors. Holes are preserved for the door socket or frame. Illustrations 2 and 5 show all the thresholds sufficiently preserved for analysis, and the arrows indicate the direction in which the leaves of the doors opened. We can observe a consistent, rational principle of movement. Let us examine, for example, the following series: a) from Rooms 41 to 38 to 39 to 40 , b) from 38 to $37-35$ to 28 , and c) from 44 to 54 or 45 . In all these cases the direction in which the doors open leads from outer to inner areas; the same principle can be observed in the arrangement of doors in the residence at Gla (ill. 4). It is probably an adaptation of the well known Minoan system of door construction in which doors also open from front rooms into back rooms and in the same direction as the principal flow of traffic along corridors. ${ }^{13}$

visit to Gla in 1976.

${ }^{12}$ See J.C. Wright, "Mycenaean Palatial Terraces," AthMitt 95 (1980) 59-86, where a modular arrangement of suites is identified in the earliest stages of construction, i.e., the foundations, of palatial structures at Pylos, Tiryns and Gla.

${ }^{13}$ See: J.W. Graham, The Palaces of Crete (Princeton 1962) 86-87, 96-97, and esp. 171-79. 

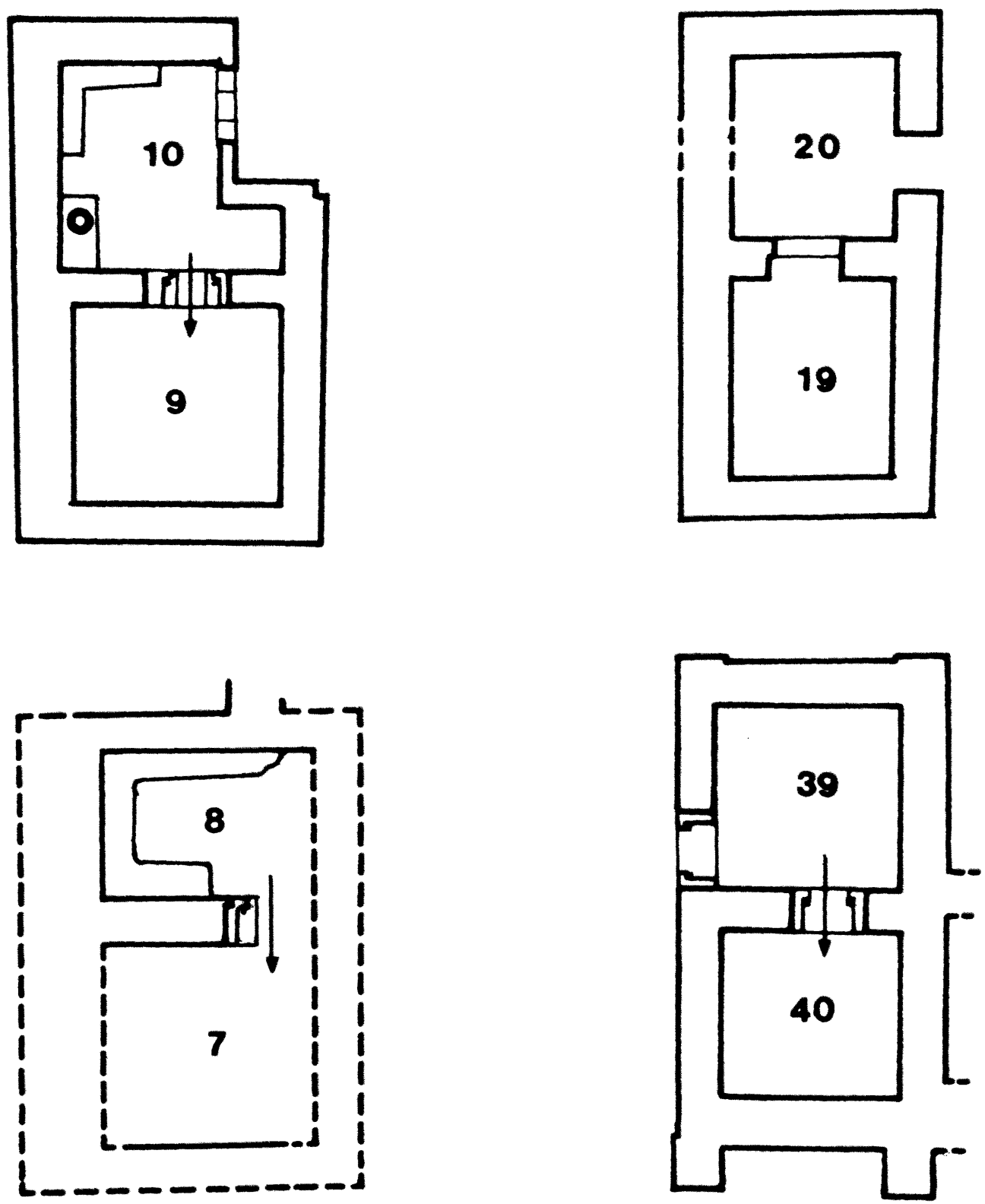

IIl. 5. Pylos, plan of two-room suites

Since it is beyond the scope of this article to analyze the many instances of this practice at Pylos, we focus on a series of two-room suites planned much like the $\mathrm{AC}$ and better preserved. They all resemble Rooms 7 and 8 in size and arrangement and thus illustrate well how Mycenaeans designed their palaces by repeatedly using similar units to create a standard suite. The best preserved are those formed by Rooms $39-40$ and 
Rooms 9-10, while others may be recognized in Rooms $19-20^{14}$ and, perhaps, Rooms $67-68$ of the Southwestern Building (ill. 5). The first two are remarkably similar in size and would be mirror images of each other except that the entrance to Room 10 has been modified to allow for passage between Room 12 and Court 3. In all four suites the direction in which the doors open indicates primary traffic from outside into a front room $(39,10,20,67)$ and then into a back room $(40,9,19,68)$ that could be closed or even locked from within. Similar suites are also found at Gla and Tiryns. ${ }^{15}$

These two-room suites constitute a repeated element of design to which Rooms 7 and 8 of the AC should conform, so it is essential to know which was the front room and which the back. Fortunately, one preserved feature of the AC is the crosswall between Rooms 7 and 8 (see the preserved section and a portion of the door jamb and threshold in ills. 2, 6), of which enough remains to determine that the internal door opened from Room 8 into Room 7. Thus, in terms of architectural conception, Room 8 was the front room and Room 7 the back room. The parallels suggest that Room 8 would have had the main outside doorway (ill. 1b). This reconstruction accords with Bennett's observation about the distribution of the Linear B tablets on either side of the "Chasm," where this doorway through the east wall would have been.

How strictly may we press this architectural analysis? Are we to assume that there was no direct access to Room 7 from the outside? If that were the case, a different explanation would have to be found for the anomalous position of the sentry stand in front of the Propylon. There seems no reason to challenge Blegen's interpretation of this block, or his reconstruction of a door from Portico 1 into Room 7. Unless a better explanation can be found, therefore, any convincing account of the function of the Archives Rooms must consider the possibility that the AC had two external doors.

Epigraphical evidence gives us a second way to interpret the function of the $\mathrm{AC}$, and serves as a check on

\footnotetext{
${ }^{14}$ Room 20 has two doors, but the door between Court 88 and Room 20 was added during a later rebuilding of the northwest quarter of the palace $(P N 45)$ when corridor 18 was blocked up $(P N$ 119). In fact, the threshold of this possible later door does not resemble the normal type used in the palace. The evidence for this change is presented by Wright, "Changes in Form and Function of the Palace at Pylos," PCA 19-29.

${ }^{15}$ Examples with slight differences occur at Gla: Wright (supra n. 12) 69, fig. 5; and Tiryns: K. Müller, Tiryns 3. Die Architektur der Burg und des Palastes (Augsburg 1930) pl. 1, rooms XI (the bath), XXI-XXII, XXV, XXVII.

${ }^{16}$ A summary account of progress in this area is given in T.G. Palaima, "The Organization of Scribal Administration at Pylos,"

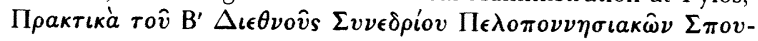

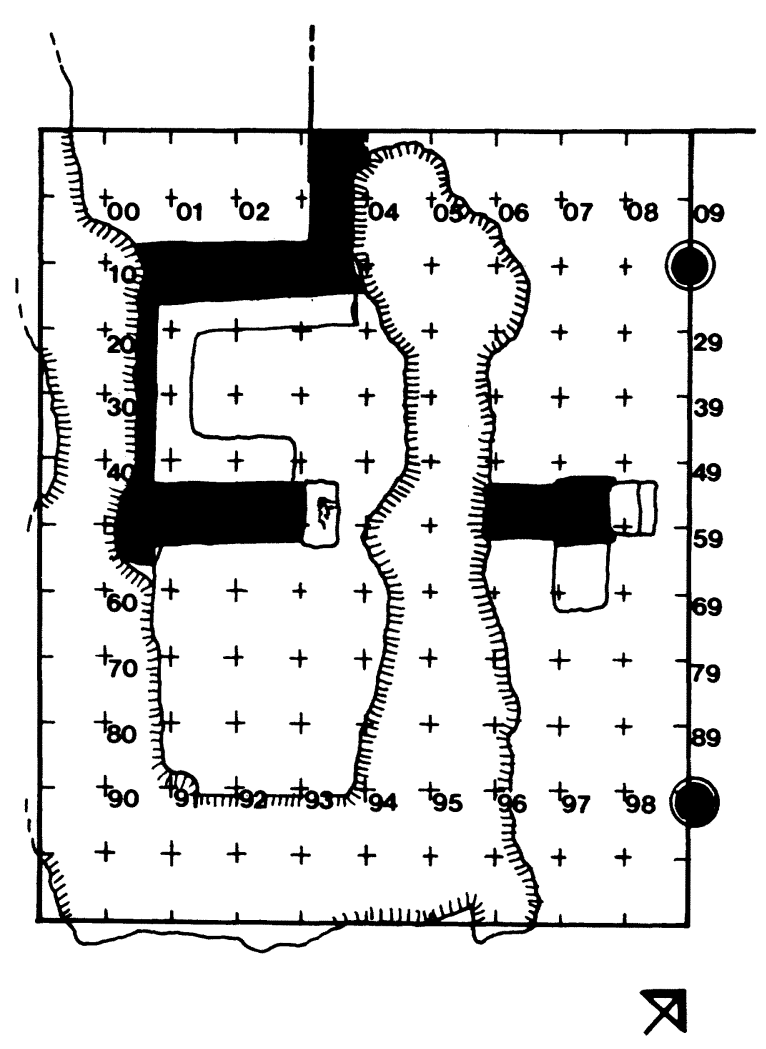

Ill. 6. Pylos, gridded plan of Archives Room

the validity of the purely architectural arguments just discussed. These epigraphical data can be used to investigate and understand: 1) the patterns of scribal activity in the Palace of Nestor; 2) the movement of tablets and scribes between the AC and other locations inside and outside the palace proper; and 3) the reception, handling, filing and storage of tablets in the AC.

We can develop a fairly exact picture of scribal activity at Pylos by studying the find contexts of the Linear B tablets assigned to recognizable scribal hands. ${ }^{16}$ The distribution of tablets, subject matter and scribes is best seen in the breakdown by room and area presented in Tables 1 and 2. It is important to keep in

$\delta \hat{\omega} \nu$ (Athens 1982) 314-20 and "Scribal Organization and Palatial Activity," PCA 31-39. We use the following terms: Hand (abbreviated $H$ ): a securely identified scribe to whom tablets have been definitely ascribed; Stylus (abbreviated S): a discernible set of tablets with a coherent palaeographic style, yet lacking evidence sufficient for designation as a Hand or for attribution to an already identified Hand; Class (abbreviated C): general class of writing style, of which there are four at Pylos. See PTT 2.7-9 for fuller explanations.

Ideograms are referred to by the standard Latin abbreviations or the numbers established by the Wingspread convention. See PTT 2.150 for a chart of the ideograms. Tablets are classified in series by subject matter (capital letter) and size (small letter: $a-m=$ leafshaped; $n-z=$ other, generally page-shaped). 
Table 1. Tablet Finds from Areas outside the AC

\begin{tabular}{|c|c|c|c|}
\hline LOCATION & SUBJECTS & SERIES & SCRIBES \\
\hline \multirow{2}{*}{$\begin{array}{l}\text { Room } 6 \\
\quad \text { (fallen from above) }\end{array}$} & textiles (TELA, LANA) & $\mathrm{La}$ & H13, S628 Ciii, S632 Ciii \\
\hline & $\begin{array}{l}\text { women (MUL) involved } \\
\text { in textile work }\end{array}$ & $\mathrm{Ae}$ & \\
\hline Room 20 & inventory of vessels & Tn 996 & Ciii \\
\hline Room 23 & oil & $\mathrm{Fr}$ & H2, H44, S1217 Cii, S1219 Cii \\
\hline Room 24 & oil & Wr 1247 & ---- \\
\hline Room 32 & oil & $\mathrm{Fr}, \mathrm{Wr}$ & H2, H34, S1203 Cii \\
\hline Room 38 & oil & $\mathrm{Fr}$ & H2, H4, H41, S1203 Cii \\
\hline \multirow[t]{2}{*}{ Courtyard 47} & $* 189$ & Qa $1259+$ & H15 \\
\hline & livestock $\left(\mathrm{CAP}^{\mathrm{f}}\right)$ & Gc $1258+$ & $\mathrm{H} 21$ \\
\hline \multirow[t]{2}{*}{ Rooms 55 and 57} & male landholders (VIR) & Ae 995 & H91 \\
\hline & $*_{252}$ & Ua $994 \dagger$ & $\operatorname{Civ}(?)$ \\
\hline Courtyard 63 & oil, DI & Fr, Ua & H2, Ua 1252 Ciii \\
\hline Room 65 & ----- & $\mathrm{Xa} 184$ & Xa 184 Ciii \\
\hline Rooms 71 and 72 & ----- & $\operatorname{Fr}(?), \mathrm{Xa}, \mathrm{Xn}$ & Cii \\
\hline Area 91 & ---- & $\mathrm{Xa} 639, \mathrm{Xn} 1261 \dagger$ & ---- \\
\hline \multirow[t]{6}{*}{$\begin{array}{l}\text { NE Workshop } \\
\quad(\text { Rooms } 95 \text { and 99) }\end{array}$} & $\begin{array}{l}\text { agricultural produce } \\
\text { (GRA, VIN, NI) }\end{array}$ & Un & H34, Un 1319 Cii, Un 1322 Cii \\
\hline & $\begin{array}{l}\text { horse trappings, chariot equip- } \\
\text { ment and male personnel }\end{array}$ & $\mathrm{An}, \mathrm{Sa}, \mathrm{Ub}, \mathrm{Va}$ & $\begin{array}{l}\text { H12, H26, H31, An } 1282 \text { Ciii, } \\
\text { Va } 1323 \text { and } 1324 \text { Cii }\end{array}$ \\
\hline & leather and ivory & Ub & $\mathrm{H} 32$ \\
\hline & $\begin{array}{l}\text { livestock (CAP, CAP } \\
\text { CAPm }^{\text {, OVIS, OVIS }}{ }^{\mathrm{m}} \text { ) }\end{array}$ & $\mathrm{Cc}, \mathrm{Cn}, \mathrm{Wr}$ & H21, H31, S1331 Ci, Cn 1286 Cii \\
\hline & single entries of men (VIR) & Ac & S1272 Ciii \\
\hline & $* 189$ & Qa & H15, H33 \\
\hline W of Room 103 & oil & Fr $1338,1355 \dagger$ & Cii \\
\hline $\begin{array}{l}\text { Wine Magazine } \\
\text { (Room 105) }\end{array}$ & wine & $\mathrm{Wr}$ & $\begin{array}{l}\text { H13, S628 Ciii, Wr } 1361 \text { Ci, } \\
\text { Wr } 1358\end{array}$ \\
\hline
\end{tabular}

† Correct findspots for Qa 1259 and Cc 1258: Marion Rawson (1956) 74; Ua 994: Carl Blegen (1953) 25, 29; Xn 1261: Marion Rawson (1956) 72; Fr 1338: Marion Rawson (1957) 102.

mind when interpreting this information that the actual tablets and their locations were accidentally preserved in the destruction of the palace by fire and therefore represent only the records that existed on clay in these areas at that single moment: We should think of our view as a snapshot or freeze-frame in contrast to a motion picture of activity over a longer period. Our task is to take this static picture and make observations about the pattern of record-keeping activity that may be valid for longer periods in the administrative life of the LH IIIB palace.

Although most of the Pylian tablets were found in the AC, many (nearly 200), dealing with diverse sub- jects, were found elsewhere in the palace, often in direct association with the materials they record. The clearest instances are the oil tablets and sealings ( $\mathrm{Fr}$, Wr) found in obvious oil storerooms containing oil storage and transport vessels (Rooms 23, 24, 32, and above Room 38), ${ }^{17}$ the wine sealings (Wr) from the Wine Magazine (Room 105), the vase inventory ( $\mathrm{Tn}$ 996) from a storeroom of vases (Room 20), the textile records (La) fallen from rooms above the Throne Room (Room 6), and the records pertaining to work with ivory, leather (Ub) and horse and chariot equipment (Sa, Ub, Va) from the Northeastern Workshop (Rooms 92-99). The size, format and contents of 
Table 2. Tablet Finds from the AC

\begin{tabular}{|c|c|c|}
\hline SUBJECT & SERIES & SCRIBES \\
\hline $\begin{array}{l}\text { ration lists for women and children } \\
\text { (MUL, ko-wa, ko-wo, GRA, NI, TA, DA) }\end{array}$ & $\mathrm{Aa}, \mathrm{Ab}, \mathrm{Ad}$ & $\mathrm{H} 1, \mathrm{H} 4, \mathrm{H} 21, \mathrm{H} 23$ \\
\hline $\begin{array}{l}\text { lists of men: rowers, military personnel attached } \\
\text { to o-ka, other occupations (VIR) }\end{array}$ & An, Ac & H1, H3, H21, H22, H24, H41, H42, H43 \\
\hline landholding records & $\begin{array}{l}\mathrm{Aq}, \mathrm{Ea}, \mathrm{Eb}, \mathrm{Ed}, \mathrm{En} \\
\mathrm{Eo}, \mathrm{Ep}, \mathrm{Er}, \mathrm{Es}\end{array}$ & $\mathrm{H} 1, \mathrm{H} 21, \mathrm{H} 24, \mathrm{H} 41, \mathrm{H} 43$ \\
\hline $\begin{array}{l}\text { agricultural produce (CYP, HORD, OLIV, } \\
\text { GRA, NI) }\end{array}$ & $\mathrm{Fa}, \mathrm{Fg}, \mathrm{Fn}$ & $\mathrm{H} 1, \mathrm{H} 2, \mathrm{H} 21, \mathrm{H} 42, \mathrm{H} 45$ \\
\hline oil & Fr 1184 & $\mathrm{H} 2$ \\
\hline $\begin{array}{l}\text { assorted commodities listed together: } \\
\text { spices, wine, oil, livestock, wool, } \\
\text { grain, olives, cloth, unidentified }\end{array}$ & Ua, Un & H1, H6, H15, H24, H42 \\
\hline bronze allotments and totals & $\mathrm{Ja}, \mathrm{Jn}$ & $\mathrm{H} 2, \mathrm{H} 21$ \\
\hline gold & Jo 438 & $\mathrm{Ci}$ \\
\hline proportional taxes and exemptions & $\mathrm{Ma}$ & $\mathrm{H} 2$ \\
\hline $\begin{array}{l}\text { lists of similar commodities as in Ma: } \\
\text { RI, ME, } O *^{*} 146, * 152, * 249\end{array}$ & $\mathrm{Mn}$ & $\mathrm{H} 2$ \\
\hline $\begin{array}{l}\text { individual records of flax deliveries } \\
\text { with totals and lists }\end{array}$ & $\mathrm{Na}, \mathrm{Ng}, \mathrm{Nn}$ & H1, S337 Cii \\
\hline$* 154$ & On & S300 Cii \\
\hline$* 169$ & $\mathrm{~Pa}, \mathrm{Pn}$ & H2, S49 Ciii \\
\hline chariot equipment & $\mathrm{Sa}$ & $\mathrm{H} 26$ \\
\hline armor & $\mathrm{Sh}$ & S733 Cii \\
\hline inventory of furniture, vases & $\mathrm{Ta}$ & $\mathrm{H} 2$ \\
\hline list of precious offerings & Tn 316 & $\mathrm{H} 44$ \\
\hline single entries and lists without ideograms & Va, Vn & $\mathrm{H} 1, \mathrm{H} 3, \mathrm{H} 12, \mathrm{H} 25, \mathrm{H} 42$ \\
\hline $\begin{array}{l}\text { labels for various sets of tablets } \\
(\mathrm{Aa}, \mathrm{Cn}, \mathrm{Ea}, \mathrm{Ma}, \mathrm{Na}, \mathrm{Sa}, \mathrm{Sh}, \mathrm{Un})\end{array}$ & Wa & $\mathrm{H} 1, \mathrm{H} 2, \mathrm{H} 24, \mathrm{H} 26, \mathrm{H} 41$ \\
\hline
\end{tabular}

these records indicate that they were designed to keep track of individual transactions, work at hand, deliveries and disbursements in the work and storage areas of the palace. Consequently, they are predominantly shorter, leaf-shaped documents (Ac, Ae, Cc, Fr, La, $\mathrm{Mb}, \mathrm{Ob}, \mathrm{Qa}, \mathrm{Ua}, \mathrm{Va})$ in contrast to the longer lists (An, Aq, Cn), compilations (En, Ep), totals (Ja, Ng) and summaries (Er) found in the AC.

Yet we should not assume that this difference in types of tablets reflects a rigid dichotomy. ${ }^{18}$ Within the AC are series of tablets that resemble texts generally found in other parts of the palace. Good examples are the leaf-shaped Sa and Sh tablets, which record chariot equipment and armor respectively, and the $\mathrm{Ta}$ tablets, which are obviously inventory records. ${ }^{19}$ Such

\footnotetext{
${ }^{18}$ Palaima thanks J.-P. Olivier for a personal communication (32-81) on this point.

${ }^{19}$ Compare the Ta tablets with PY Tn 996 and MY Ue 611, which were found in definite storage contexts. Tn 996 lists eight different types of vessels and comes from a storeroom (Room 20) that contained about 521 pots of at least 25 different shapes. The
}

records and inventories were brought from workrooms and storerooms for processing and storage in the AC-as confirmed by two cases where sets of related documents were found partly in the $A C$ and partly in the Northeastern Workshop. ${ }^{20}$

Scribal attributions offer further proof of interaction between the AC and other areas of the palace proper and its appendages. Again allowing for the fact that we are looking at a snapshot of scribal work, we can make several valid observations. Of the 25 securely identified scribes from the destruction phase of the palace, only seven are attested by tablets found exclusively outside the AC, and in each case the number of surviving tablets is relatively small. Hand 13 recorded textile work in the area above Room 6 and per-

tablet may have been stored on a shelf in the southeastern corner of the room along with pots: $P N 125-26$. For Ue 611 , see $M T$ 2.102-105.

${ }^{20}$ Cc series (H21): 2 tablets in AC, 4 in or near the Northeastern Workshop. Sa series (H26): all in AC except Sa 1313 in Northeastern Workshop. 
haps in the Southwestern Building (6-13 tablets). ${ }^{21}$ Hand 14 kept track of commodity *146 strictly in the Southwestern Building ( 32 tablets). Hands 31 (2 tablets), 32 (3 tablets), 33 (4 tablets) and 34 (2 tablets) are attested solely in the Northeastern Workshop. There is no indication that any of these sets were intended to be filed or stored for long periods in the areas where they were found. Perhaps they would eventually have been transported to the AC if the destruction of the palace had not intervened.

Of the 18 hands represented in the $\mathrm{AC}$, the tablets of 9 are found only here, but again the number of tablets attributed to each scribe is relatively small. ${ }^{22}$ This exclusivity, then, may be more apparent than real, especially when we consider the 9 other scribes whose work is found both in the AC and elsewhere. Hand 2 wrote important sets of tablets ( Jn, Ma, Mn, Ta) found in the AC, but also leaf-shaped oil tablets from Rooms 23, 32, 38, and Court 63. Hand 4 shows a similar division: women's ration lists in the AC, oil tablets in Room 38. Hand 44 wrote the notorious record of precious offerings ( $\mathrm{Tn} 316$ ) from the AC and a more mundane text concerned with the distribution of scented oil from Room 23. Work by Hand 21 encompasses important records of landholdings (Aq), ration allotments $(\mathrm{Ab})$, livestock $(\mathrm{Cc}, \mathrm{Cn})$ and bronze disbursements (Jn) from the AC and leaf-shaped livestock records (Cc) from the Northeastern Workshop. The work of these better attested scribes establishes a pattern of movement to and from the AC. The scribes moved throughout the palace wherever the need for record-keeping arose.

How do the AC and its architectural reconstruction thus far fit into this overall pattern? First, we should make note of the small size of the rooms, each roughly 4 $\mathrm{m}^{2}{ }^{2}$, which is further reduced by requirements for storage (benches, shelves) and for general use (the large pithos in the south corner of Room 7). ${ }^{23}$ It is virtually certain that record-keeping was done outside of these small rooms except perhaps in the case of the master

\footnotetext{
${ }^{21} \mathrm{Wr} 1359$, a sealing with the wine ideogram and a fragmentary inscription found in the Wine Magazine (Room 105), is attributed to Hand 13. This sealing, like others in Rooms 24, 98 and 99, may have been attached to a shipment and then discarded at the point of delivery. It therefore need not prove the presence of Hand 13 in Room 105. The same applies to the sealing by Hand 34 from Room 32. On sealings generally, see MT 2.103-105, and V.L. Aravantinos, "The Use of Sealings in the Administration of Mycenaean Palaces," PCA 41-48.

${ }^{22}$ Hands 1, 6, 11, 22, 23, 24, 25, 42 and 45 are attested solely in the AC or in contexts resulting from the later robbing of the outer walls. The most notable exception in terms of numbers of tablets is Hand 1, the master scribe or archivist, who may have worked exclusively in the AC. See T.G. Palaima, "Evidence for the Identification of a Master Scribe at Pylos," AJA 84 (1980) 226.
}

scribe (Hand 1) who helped organize and systematize the handling of tablets in the AC. The restriction of space also eliminates the possibility of long-term filing of extremely large numbers of records.

The distribution of scribes and tablets discussed above reveals both internal and external patterns of movement. These patterns were governed by the state of the palace in its final phase (ill. 2), during which the original layout underwent considerable alteration. ${ }^{24}$ The western side of the palace was effectively sealed off by a crosswall at the northwest limit of area 88 and by construction of the complex of Rooms 59-61, which limits access to Court 63. The eastern side of the palace was closed off by Courts 42 and 47 . Crosswalls were even placed at the northwest and southeast ends of Corridor 18. Thus we must imagine internal routes of circulation for the scribes working in the palace proper, whether on the ground floor in the oil storage areas (Rooms 23, 24, 32) or on the upper floor above Rooms 6 and 38. The scribes on the upper floors would have moved along the following logical routes to and from the AC: $54-44-3-2-8,36-$ 35-37-44-3-2-8, 15-14-13-12-11-3-2-8. For this scribal traffic it would have been more sensible to enter the AC through Room 8 than to leave the palace by the main entrance and then to enter the AC via Room 7. The scribes coming from the Southwestern Building and the rear storerooms of the main building (Rooms 20, 23, 24) would most conveniently have taken routes determined by the architectural modifications: 88-63-12-11-3-2 and 64-63-12-11-3-2, again into Room 8.

We also have to be concerned with external movement from areas such as the Northeastern Workshop and the Wine Magazine, not to mention records, scribes and information that may have come from outlying centers in the district controlled by Pylos. ${ }^{25}$ For this flow of recorded information, direct access to the exterior room (Room 7) seems most logical and would explain the unusual placement of the sentry stand as

\footnotetext{
${ }^{23} \mathrm{PN} 92-100$.

${ }^{24} \mathrm{~A}$ thorough analysis of the alterations to the palace is presented by Wright (supra n. 14). There is no confirming evidence for the presence of a door connecting Room 12 with Court 63 since the foundations of the outer palace wall at that point were all robbed out.

${ }^{25}$ To cite a few examples, information had to be gathered about herds of livestock $(\mathrm{Cn})$, landholdings in the district of $p a-k i-j a-n a$ $(\mathrm{En})$, flax deliveries from locales in both provinces $(\mathrm{Na}, \mathrm{Ng})$, and even the allotment and collection of bronze involving various smiths and officials in outlying districts $(\mathrm{Jn})$. The implications of a comparable information-gathering process at Knossos are discussed by J.P. Olivier, "La série Dn de Cnossos," SMEA 2 (1967) 86, and A.L. Wilson, "Preliminary Considerations on the Knossos PlaceNames," Minos 16 (1977) 95-96.
} 
discussed above. Thus, it seems most likely that the AC had two doors, one into Room 8 and one into Room 7. It may be, however, that the suggested entrance to Room 7 was added later, necessitated by the addition of the outlying structures of the palace and its internal remodelling. ${ }^{26}$

How does our last category of epigraphical evidence, that of the findspots, labels and sealings from the AC proper, relate to our proposed reconstruction? The finds from inside the AC have never been thoroughly studied. ${ }^{27}$ How are we to interpret the nature and value of these records, sealings and labels and their storage facilities within the overall palatial administration? In order to explain the odd placement of the sentry stand, Blegen hypothesized that the AC was "probably the office of the tax collector" or "may have been a treasury office," ${ }^{28}$ thus attributing to the rooms a status of sufficient importance to warrant special security precautions. Moreover, the very designation of the rooms as palatial archives introduced ideas of importance and permanence associated with the formal archives of the ancient Near East and modern research collections. ${ }^{29} \mathrm{We}$ can better assess the role of the AC at Pylos by setting aside these assumptions and studying the finds from the rooms.

Let us first look at the distribution of tablets within the AC (ill. 6). Most of them were discovered in Room 8 where they had been stored on shelves alongside or above the northern clay bench that runs through grids 10-13 (ill. 6). The storage of tablets in this room was confirmed by the discovery of clay labels in direct association with related sets of tablets: Wa 114 (Hand 1) in grid 13 with the Aa tablets of Hand 4; Wa 1008 (Hand 1) in grid 13 with one tablet from the Aa set of Hand 1, the other tablets of which had spilled across Room 8 through the doorway and into grids 54, 64 and 74 of Room 7; Wa 1093 in grid 34 labelling four $\mathrm{Na}$ tablets that again had spilled across the floor into

\footnotetext{
${ }^{26}$ Unfortunately there is evidence neither from the remains of Room 7 nor from the sentry stand next to it to support this suggestion. Wright (supra n. 14) has argued that the placement of the sentry stand within area 1 of the southern propylon may have occurred during the last remodelling of the palace.

${ }^{27}$ Bennett (supra n. 8) did the yeoman's work of identifying the findspots of the tablets from the AC. In addition, J. Chadwick has made occasional remarks about the association of a few labels and tablet series, "The Mycenaean Filing System," BICS 2 (1958) 1-5, and more recently has given a brief, imaginative reconstruction in The Mycenaean World (Cambridge 1976) 18-27, figs. 8 and 9.

${ }^{28}$ PN 92-93.

${ }^{29}$ Excavators have been all too ready to call archives any group of tablets found together (see supra $n$. 2). This designation fails to recognize the obvious differences in importance and purpose between documents formally collected, processed and filed, and documents of the kind found in single workrooms and storerooms at
}

grids 23, 33 and 75. The tablets in Room 7 mostly come from the spillage just mentioned. The vast majority belongs to sets found in Room 8 and comes exclusively from those grids $(53-55,63-65,73-75$, 83-85) which line up with the doorway between Rooms 7 and 8, only a very few small fragments slightly rounding the corner. The four En tablets provide the clearest and simplest example with components in grids 13, 14, 43, 63 and $64 .{ }^{30}$

This pattern of distribution proves that most of the tablets, even those found in Room 7, were stored in Room 8 at the time the palace was destroyed. Can we discover how they got to Room 8 ? Here the clay labels and the few tablets that do come from Room 7 provide the answer. Twelve clay labels were discovered in Room 7 and only seven in Room 8. This is a surprising ratio given the overwhelming evidence for the storage of tablets in Room 8. Nine of the labels from Room 7 were found clustered together in grid 5214, which is just to the left of the doorway into Room 8 . Only one of these nine is associated with the set of tablets that it identifies: Wa 732 and the Sh tablets, all from grid 52. We should remark that the dozen Sh tablets are the sort that one expects to have come from outside the AC. They are carelessly manufactured (four are palimpsestic), show the uncertainty in formulae and format that betrays extemporaneous work, and give an inventory of pieces of armor that no doubt were stored elsewhere, perhaps in the Northeastern Workshop.

On this analysis we can suggest that grid $\mathbf{5 2}$ was approximately where the scribes placed labelled baskets of tablets brought into Room 7 through the outer door. This theory would explain why other labels found in grid $\mathbf{5 2}$ go with sets of tablets that were found in Room 8 completely dissociated from their labels. ${ }^{31}$ These were not, as is usually thought, purely filing labels, but transport labels attached to wicker baskets

Pylos, Mycenae, Thebes and Knossos. A particularly misleading identification is that of the small group of Of tablets from Thebes. They were found in a probable wool-working room, but the room was called the "Archive Room" because tablets were found there. See J. Chadwick and T. Spyropoulos, The Thebes Tablets 2 (Salamanca 1975) 22-23, 85-107.

${ }^{30}$ Series: grids containing tablet components of this series: $\mathrm{Ab}$ : 13, 22-25, 33, 34, 52 ( 2 of $84 \mathrm{Ab}$ tablet components), 64, 83. Ad: 12, 13, 22-24, 53, 54, 63, 64, 83. Ea: 11-13, 22, 23, 26, 31, 32, 53, $54,64,65,74,75,84$. Eb: 12-15, 17, 23-27, 32-36, 45, 52 (2 of 193 Eb tablet components), 55, 64, 65, 74, 75, 85. Jn: 11-13, 22, 23, 25-27, 33, 35, 44, 45, 54, 55, 63, 64, 73, 75, 83, 84. Na: 12, 13, 22, $23,25,33-35,43-45,53,54,56,64,65,75,85$. Sa: 12, 22, 23, 31, $35,45,52$ ( 1 of 97 Sa tablet components), 53, 54, 64, 65, 73-75, 84

${ }^{31} \mathrm{Wa} 730$ : Ma tablets in grids 13, 23, 34; Wa 930: Cn tablets in grids $22,23,32,33,34,45$; $\mathrm{Wa} 948$ : $\mathrm{Na}$ tablets primarily in grids $12,13,23,33,34$. 
in which tablets were carried to the AC. These baskets were then placed conveniently beside the door leading from Room 7 to Room 8. Meanwhile their sets of tablets, all dealing with external matters (series $\mathrm{Cn}, \mathrm{Ma}, \mathrm{Na}, \mathrm{Sh}$ ), were taken out and processed. The tablets would then have been taken into Room 8 for longer storage, or they would then have been repulped (perhaps using water stored in the pithos) when the information on them was no longer of use. ${ }^{32}$ The tablets could have been put in Room 8 in the wicker baskets in which they arrived at the AC, which would explain why some labels were found in Room 8. Usually, however, they were stored in permanent wooden filing boxes along the shelves. ${ }^{33}$ Here palace officials could refer to their contents by entering through the door directly into Room 8, where they could sit and lay out the tablets on the western and southern benches. ${ }^{34}$ The fire that destroyed the Palace of Nestor swept through the Archives Rooms after the tablets of series $\mathrm{Cn}, \mathrm{Ma}$ and $\mathrm{Na}$ had been processed and taken to Room 8, but while the Sh tablets were still in their delivery basket in Room 7. The labels remained where the baskets for all these series had originally been placed, in grid 52. Our interpretation of labels and tablets thus lends support to the reconstruction of two entrances to the $\mathrm{AC}$, one in each room, providing access for scribes working inside and outside the palace. We can now consider the role of the Archives Rooms within the general record-keeping system of the palace.

First, we should stress that nowhere in MinoanMycenaean record-keeping is special care taken to guard records kept on clay. The placement of rooms used for collecting tablets depends totally upon convenience of access to places requiring or producing records. ${ }^{35}$ So, for example, neither of the possible "ar-

\footnotetext{
${ }^{32}$ For evidence of repulping in the AC, see $P N 99$.

${ }^{33} P N 99$ gives the evidence for wooden boxes in Room 8 and at Knossos. We should note that Room 8 contained 11 sealings, 7 in direct association with tablets. Room 7 contained only one sealing, again in grid 52. This sealing lay in context with Es 650 of Hand 11. A sealing in Room 8 was made by the same seal (CMS I.344, no. 307, NM 8477) and was found in grid 31 with the one other tablet by Hand 11, An 18. It would seem from these associations that sealings were used to prevent tampering with closed wooden boxes storing tablets in Room 8. PN 95, 98-99, lists and describes the sealings from Rooms 7 and 8. PTT 1.261 and 266 explains the difference between sealings and labels.

${ }^{34}$ Palaima thanks C.W. Shelmerdine for calling to his attention the special suitability of the clay bench in Room 8 for the recordkeeping activities that took place there.

${ }^{35} \mathrm{G}$. Goossens, "Introduction à l'archivéconomie de l'Asie antérieure," RAssyr 46 (1952) 103, formulated this principle for Near Eastern scribal systems. Mycenaean-Minoan examples: Bureaux $\mathrm{C}$ and I at Knossos, J.-P. Olivier, Les scribes de Cnossos (Rome 1967) 66-76, 126-29; Rooms 7 and 8 at Pylos; northwest area at
}

chives" at Knossos suggests that any attention was paid to the security of the rooms. ${ }^{36}$ Second, we should not forget that clay tablets are the provisional, immediate notes of record, the significant details of which would have been kept more permanently on papyrus or parchment, most likely on the upper floors of the palace. ${ }^{37}$ We should envision the $\mathrm{AC}$ at Pylos not as a location for storing vital documents through long periods of time (this function is precluded by limited space), but as an active center for processing records, with a constant flow of information in and out. The tablets of the E- series reveal the initial stages of such processing, wherein Hand 1 reduces individual records to condensed formats and summaries, perhaps to be committed eventually to papyrus. Our snapshot provides a picture of this material frozen in the act of transformation.

If the records in the AC did not require special protection, why is the sentry stand oddly placed? We suggest that the sentry was to prevent unwelcome strangers from using the outer door in Room 7 to gain access to the rest of the palace through the door in Room 8 . We have mentioned that the Pylians carefully restricted entry into the palace in late LH IIIB. The only entrances were in the southeastern facade: through the southern Propylon (Rooms 1 and 2), through the corridor leading through Rooms 59-61, and, we maintain, through Rooms 7 and $8 .{ }^{38}$ Once we realize that the records in the AC did not merit elaborate security precautions, only the possibility of access to the entire main building explains the unorthodox placement of the sentry stand. For this reason, too, we propose a restoration of doors into both Rooms 7 and 8 .

In sum, study of the architectural and epigraphical data offers evidence for a more detailed explanation of the activities associated with the Archives Rooms than

Agia Triadha, M. Pope, "The Gretulae and the Linear A Accounting System," BSA 55 (1960) 200-201.

${ }^{36}$ Olivier (supra n. 35) 21, C and I. Detail of C in L.R. Palmer, "The Find-Places of the Knossos Tablets," On the Knossos Tablets (Oxford 1963) plan I, areas 8 and 9.

${ }^{37}$ For the accepted view of the existence of papyrus or parchment records, see Chadwick (supra n. 27) 27-28 and Pope (supra n. 35) 201. This view is now corroborated by I. Pini's thorough study of sealings $\mathrm{f}_{\mathrm{l}} \rightarrow$ Zakros, "Neue Beobachtungen zu den tönernen Siegelabdrücken von Zakros," $A A$ 1983, 559-72. See also J. Weingarten, "The Use of the Zakro Sealings," Kadmos 22 (1983) 8-13. For storage of papyrus records on upper floors, see Pope (supra n. 35) 200.

${ }^{38}$ Mabel Lang proposed to us that a ticket window in Room 7 would satisfy the need to make external deliveries and would also explain the distribution of tablets and labels, as discussed above. The guard stand, however, suggests the existence of a doorway because a small ticket window would itself insure the security of the $\mathrm{AC}$ and the rest of the palace from intrusion and not require a guard stand to the left of a person entering. 
has heretofore been proposed. Insights have been provided into the disposition of the Linear B documents in this suite of rooms. The suggested reconstruction of two doors accommodates the internal and external patterns of scribal activity and suits the function of the Archives Rooms as the central hub of record-keeping in the architecturally modified late LH IIIB palace. Our analysis corrects unwarranted assumptions about the importance of the archives. We have also demonstrated that the Mycenaeans employed rational methods of palace planning which, although suspected in the plans of the other palaces, are not so clearly docu- mented elsewhere. ${ }^{39}$ The Palace at Pylos thus continues to be a rich source for research and analysis of the problems of Mycenaean palatial organization.

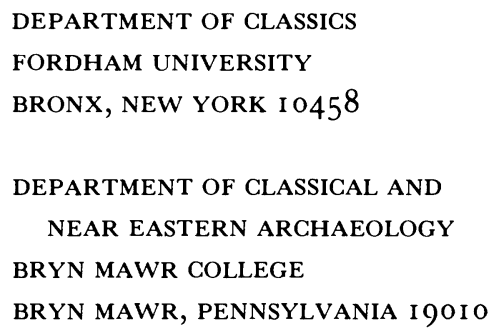

${ }^{39} \mathrm{Cf}$. Wright's analysis of the northeastern residential quarter at Tiryns, (supra n. 12) passim, and Müller, Tiryns 3 (supra n. 15) 167-71; see also the plan of the early "mansion" at the Menelaion which, although simpler, is remarkably similar to that of the main building at Pylos: H. Catling, "Excavations at the Menelaion, Sparta, 1973-1976," JHS-AR 23 (1976-1977) figs. 2, 5. 